\title{
To Flee or Not to Flee? Matthew 10:23 and Third Century Flight in Persecution
}

\author{
Ruth Sutcliffe \\ Christ College, Sydney Australia \\ ruthie.sutcliffe@gmail.com
}

\begin{abstract}
When faced with persecution, Christians behaved in a range of ways, from confessing and accepting (or even provoking) martyrdom to apostasising. Another option was to flee. Tertullian's perspective on flight varied with the rhetorical purposes of his writings. Other third century writers, notably Clement, Origen and Cyprian, argued that flight was a viable option in order to make life safer for those left behind, to avoid being complicit in the persecutors' sin and for preservation in order to continue one's work and witness. All four cited or alluded to Matthew 10:23 in support of their position. This paper explores the theological and contextual factors which informed their differing exegesis of this passage, concluding that theology was the primary influence for Clement and Origen, rhetorical aims for Tertullian, and for Cyprian, the role and duty of the bishop in changing circumstances.
\end{abstract}

\section{Keywords}

martyrdom - Tertullian - Cyprian - Origen - Clement of Alexandria - Matthew 10:23

Clement, Origen and Cyprian escaped persecution by departing; Cyprian later accepted martyrdom and Origen suffered under torture. Tertullian neither fled nor was martyred, but opposed fleeing persecution. Each referred or alluded to Mt 10:23 in defence of their positions. This essay will demonstrate that the primary exegetical influence for Clement and Origen was theological, for Tertullian rhetorical objectives, and for Cyprian, his duty as bishop in changing circumstances. 


\section{Persecution in the Third Century}

Although third century persecution was intermittent and primarily local, Christian writers certainly perceived their communities as disliked and imperilled, with popular antagonism and official intervention an impending threat, whether it materialised in a given community or not. ${ }^{1}$ The Severan disquiet in the early 200 in Alexandria and Carthage was the milieu of Clement and Tertullian. Origen and Cyprian experienced the first imperial persecution, under Decius' sacrificial edict for the pax deorum, followed by a more directed attack against Christian leaders under Valerian.

The reaction of individual Christians to persecution, or the threat of it, could be considered as a spectrum. ${ }^{2}$ The sacrificiati were those who voluntarily apostasised, denying Christ and sacrificing to the gods. ${ }^{3}$ Some caved under pressure of deprivation or torture and reluctantly apostasised. ${ }^{4}$ The libellatici paid officials to get a certificate but did not actually sacrifice. ${ }^{5}$ Stantes were those who neither fled nor presented themselves, but confessed if accused. ${ }^{6}$ Most commended were the confessores and the martyrs. ${ }^{7}$ Bribery to obtain false libelli and apostasy were denounced. ${ }^{8}$ At the far "extreme" were the socalled voluntary martyrs, who "rushed on death" or provoked their own martyrdom. ${ }^{9}$ Where did actively fleeing from persecution lie on this "spectrum," if

For discussion of the extent, nature and reasons for persecution in the early church, see W.H.C. Frend, Martyrdom and Persecution in the Early Church, Cambridge, 1965; G.E.M. de Ste. Croix, in Michael Whitby and Joseph Streeter, eds., Christian Persecution, Martyrdom and Orthodoxy, Oxford, 2006; Robert L. Wilkin, The Christians as the Romans Saw Them, 2nd ed., Yale, 2003; the skeptical perspective of Candida Moss, The Myth of Persecution, New York, 2013. and the response of Paul Hartog, "The Maltreatment of Early Christians," Southern Baptist J Theol 18:1 (2014), pp. 49-79.

Frend, Martyrdom and Persecution, pp. 409-411. Middleton argues that radical martyrdom was widely practised, despite being condemned by the fathers e.g. Clement, Strom. 4.16.317.3. Paul E. Middleton, Radical Martyrdom and Cosmic Conflict in Early Christianity (Library of NT Studies) London, 2006, pp. 23-25.

3 Cyprian, Laps. 7-8, (CCSL 3:224-25).

4 Cyprian, Laps. 13 (CCSL 3:227-28).

5 Tertullian, Fug. 12 (CCSL 2:1153-55).

6 Cyprian, Laps. 3 (CCSL 3:222) and possibly alluded to in Tertullian, Fug. 5, 8, 9 (CCSL 2:1141$42,1145-47)$ in terms of standing fast and entrusting oneself to God.

7 Clement, Strom. 4.4, (PG 8:228-29), Tertullian, Scap. 1 (CCSL 2:1127), Scorp. 2 (CCSL 2:107174), Origen, Ad Martyrum; Cyprian, Ad Fortunatum.

8 Tertullian, Fug. 12 (CCSL 2:1153-57).

9 Clement, Strom. 4.4, 10. The failure of Quintus in contrast with Polycarp's martyrdom (Martyrdom of Polycarp 4, PG 5:1032-33) may be a later insertion; see Middleton, Radical 
at all? Tertullian ultimately classed it as a weaker form of apostasy. Clement, Origen and Cyprian also lauded martyrdom but they accepted flight as appropriate. Nevertheless, the non-negotiable element was, in whatever circumstances, Christians must never deny Christ, or he in turn would deny them (Mt 10:33). ${ }^{10}$ These writings present four potential reasons for why one might flee persecution; (1) cowardly avoidance of martyrdom, (2) to make life safer for those left behind, (3) to avoid being complicit in the persecutor's sin and (4) in order to continue one's work and witness. Tertullian held that martyrdom is witness. The others did not deny that martyrdom and confession were the pinnacle of witness, but they were willing to acknowledge other forms. ${ }^{11}$

There are some scriptural precedents for flight or retreat in persecution, ${ }^{12}$ although most New Testament references to persecution and affliction emphasise endurance and patience, not withdrawal. ${ }^{13}$ The most explicit verse about flight comes from Jesus' missionary discourse to his disciples; Matthew 10:23. "When they persecute you in one town, flee to the next, for truly, I say to you, you will not have gone through all the towns of Israel before the Son of Man comes."14 Tertullian argued in De Fuga in Persecutione that it applied only to the apostles' original mission and did not justify flight in his day. In contrast, Clement, Origen and Cyprian interpreted Mtıo:23 as still applicable as a justification for withdrawal. Theological perspective drives exegesis, ${ }^{15}$ and texts

Martyrdom, pp. 25-27. Middleton shows that voluntary martyrdom may have been more "orthodox" than traditionally accepted.

This passage and its parallels in Mark 8:38 and Luke 9:26 are among the most cited passages on persecution in the four fathers; by my count 16 times in Tertullian, 1 in Clement, 2 in Origen and 11 in Cyprian.

11 Martyrdom was also seen as remitting post baptismal sin and ensuring salvation. To a disputed extent, penance (Tertullian, De Paenitentia) and good works, particularly almsgiving, were similarly advantageous. See Geoffrey D. Dunn, "The White Crown of Works: Cyprian's early pastoral ministry of almsgiving in Carthage," Church History, 73:4 (2004), pp. 715-740; Everett Ferguson, "Early Church Penance," Restoration Quarterly, 36:2 (1994), pp. 81-100.

Heb 11:37-38; 1 Ki 18:13; Mt 2:13-15, 19-22; Lk 4:28-30; Ac 8:1-3; 11:19; 13:50; 14:6, 19-21; 2 Co 11:3033

13 Mt 5:39; 10:31-32; Lk 6:22-23; 21:19; Jn 16:1-3; Ro 8:35-37; 12:14-21; 2 Co 4:8-9; 12:10; 2 Th 1:4-7; Heb 12:5-11; Jas 1:2-4; 1Pe 1:6-7; 2:18-23; Rev 2:10.

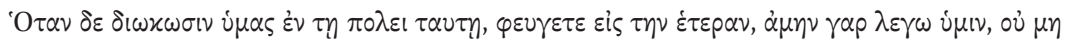

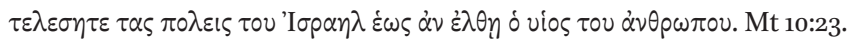

15 See Donald Fairbairn, "Patristic Exegesis and Theology: The cart and the horse, Westminster Theological Journal 69 (2007), pp. 1-19. Young notes that a disengagement between biblical exegesis and theology, or between exegesis and Christian praxis, was unthinkable to the Fathers; Frances M. Young, Biblical Exegesis and the Formation of Christian Culture, 
were received and interpreted in the context of the exegete's community and experience. ${ }^{16}$ This paper will firstly explore Tertullian's perspectives on flight through the lens of Mt 10:23, then compare and contrast the positions of Clement, Origen and Cyprian.

\section{Tertullian}

In the early reign of Severus, Tertullian briefly mentioned flight as an occasion for patience, his only acknowledgement that flight itself could be a form of suffering. ${ }^{17}$ Around this time ${ }^{18}$ he wrote to his wife, arguing that "a thing is not good merely because it is not evil." ${ }^{19}$ Remarriage is not unlawful but chastity is better. Interestingly, he used flight in persecution in support of this argument. It is better to take advantage of the permission to flee in persecution rather than be tortured into apostasy, however it is better to depart this life in blessed confession. ${ }^{20}$ During the Severan tribulation, c.203, Tertullian argued in Scorpi$a c e^{21}$ that martyrdom has been commanded by God and Christians are obliged to suffer it. ${ }^{22}$ Apostolic times were no different from the current situation. The beatitude blessing of the persecuted in Mt 5:10-12 applied to all Christians. ${ }^{23}$ He followed with Matthew 10, citing verses 16, 17-18 and 21-22, ${ }^{24}$ the problems

Peabody MS, 1997, p. 4. O'Keefe and Reno identify the patristic task of exegesis as an overall interpretation of the Christ-centred unity of Scripture, under the guidance of the rule of faith for the attaining of divine wisdom and drawing nearer to God; John J. O'Keefe and R.R. Reno, Sanctified Vision: An Introduction to Early Christian Interpretation of the Bible, Baltimore, 2005, pp. 24-25, 118, 122, 139. Young, Biblical Exegesis, p. 219 argues that context affected the way the text functioned in the community which read it.

17 Tertullian, Pat. 13.6 (cCSL 2:1144-45). c198-203 according to Timothy D. Barnes, Tertullian; A Historical and Literary Study, Oxford, 2005, pp. 38, 55.

18 Probably between 198 and 203, Barnes, Tertullian, p. 55.

19 non ideo quid bonum est, quia malum non est. Tertullian, $U x .1 .3 .5$ (CCSL 1:376).

20 Tertullian, $U x$. 1.3.4 (CCSL 1:375-76).

21 Barnes, Tertullian, pp. 38, 55. The martyrdom of Perpetua and Felicity is understood to have occurred at this time, and Tertullian refers to it in An. 55.4 (CCSL 2:862-63).

22 Tertullian, Scorp. 8 (CCSL 2:1082-84).

23 Hoc quidem absolute ad omnes; dehinc proprie ad apostolis ipsos.... apostolici seminis frutices. Tertullian, Scorp. 9.2 (ccsl 2:1082-84).

24 Nam et si rursus ad apostolos dirigit: ecce ego mittam uos tamquam oues in medio luporum, et: cauete ab hominibus; tradent enim uos in concessus et in synagogis suis flagellabunt uos et ad praesides et ad reges perducemini mei causa in testimonium illis et nationibus et cetera, tum autem subicit: tradet autem frater fratrem et pater filium in mortem et insurgent filii in 
in which were not experienced by the apostles, but apply to us, as possessors of the Name and hence objects of hatred. ${ }^{25}$ After applying what is now verse 22, "But the one who endures to the end will be saved,"26 he skipped over verse 23, asserting that there "immediately" follows what we have in verse 24, it being the duty of the Master's servants to bear the same suffering, betrayal and death. ${ }^{27}$ Tertullian then moved to discuss 10:28-33, explicitly applying this passage to disciples of his day and all times, not limiting it to the apostles - yet (without comment) omitted verse 23 about fleeing from city to city. ${ }^{28}$ In Scorpiace 11 he brought Mt 10:22, 32-33 and 35-36 into play once again, subsequently alluding to Mt 10:37-38 and citing verse 39. In Scorpiace, there is no question that Tertullian applied Matthew 10 to the persecuted Christians of his day; these things were ordained by God and had come to pass exactly as ordained. ${ }^{29}$ It is therefore remarkable, not only that Tertullian excluded verse 23 from this exegesis, but when returning to the passage in De Fuga in Persecutione, he confined its application to the original apostles in their mission to Israel.

In De Corona Militis, ${ }^{30}$ Tertullian defended the actions of a Christian soldier who had refused to wear the military garland, accusing his critics of cowardice, in an obvious reference to Mt 10:23:

So they murmur that peace ... is endangered for them. Nor do I doubt that some are already turning their back on the scriptures, are making ready their luggage, are equipped for flight from city to city; for that is all of the gospel they care to remember. ${ }^{31}$

parentes et mortificabunt eos, manifeste iniquitatem istam in ceteros pronuntiauit, quam in apostolis non inuenimus... et eritis odio omnibus propter nomen meum. Tertullian, Scorp. 9.4-5 (CCSL 2:1084-85).

Tertullian, Scorp. 9.5 (CCSL 2:1085).

26 Qui autem sustinuerit usque in finem, iste saluus fiet. Tertullian, Scorp. 9.5 (CCSL 2:1085).

27 non est discipulus super magistrum, statim sequitur, nec seruus super dominum suum, quia cum magister et dominus ipse perpessus sit persecutionem et traditionem et occisionem, multo magis serui et discipuli eadem expendere debebunt. Tertullian, Scorp. 9.6 (CCSL 2:1085).

28 Scorp. 9.7-8 (CCSL 2:1085)

29 Scorp. 11.5-8 (CCSL 2:1091-92).

$30 \quad$ Barnes, Tertullian, p. 55, originally set De Corona in early 208 but in his 2005 revision suggests a later date, 211, along with other "Montanist" works, p. 328.

$31 \quad$ Mussitant denique tam bonam et longam pacem periclitari sibi. Nec dubito quosdam scripturas emigrare, sarcinas expedire, fugae accingi de ciuitate in ciuitatem. Nullam enim aliam euangelii memoriam curant. Tertullian, Cor. 1.5 (CCSL 2:1040). 
Rather than permitting what is not expressly forbidden, Christians should abstain from what is not freely allowed, ${ }^{32}$ the argument used in Ad Uxorem, but for the opposite effect. In De Fuga, written 208-209, ${ }^{33}$ Tertullian asserted that persecution is ordained by God and therefore good. The injustice of persecution comes from the devil and is permitted by God. ${ }^{34}$ Because persecution comes from God, we should not flee it. ${ }^{35}$ To flee because one thinks one might deny is to already have given up and denied. ${ }^{36}$ Christ's instructions to the disciples to flee in Mt 10:23 do not apply to us now; they still had work to do and it was for the continuance of that work that they kept moving. ${ }^{37}$ Flight is not appropriate protection for the weak because God doesn't want us to be weak! "He does not cherish, but ever rejects the weak, teaching first, not that we are to fly from our persecutors, but rather that we are not to fear them." ${ }^{38}$ The Holy Spirit encourages us to martyrdom, not flight. It is better to die at the hands of God than to flee. ${ }^{39}$ It is a particular responsibility of the clergy not to flee. ${ }^{40}$ Tertullian argued that Mt 10:23 has been misused by some "as a cloak for their cowardice." ${ }^{11}$ This verse applied specifically and solely to one occasion and one group of people; the apostles in their initial mission to Israel. He was adamant that it did not apply beyond that to Christians in his day. Tertullian cited as evidence the context of Matthew 10 in verses $5-6,17,23$. They were not to go to the Samaritans or Gentiles but only to the lost sheep of Israel; only the apostles were brought before Jewish councils and synagogues and their mission was restricted to the cities of Israel. ${ }^{42}$ Tertullian read this as a command to not go beyond Israel, rather than a limitation of what could be accomplished "before the Son of Man comes." In fact, he omitted that clause. He simply had Jesus say; "You will not go over all the cities of Israel." ${ }^{43}$ Tertullian regarded the later

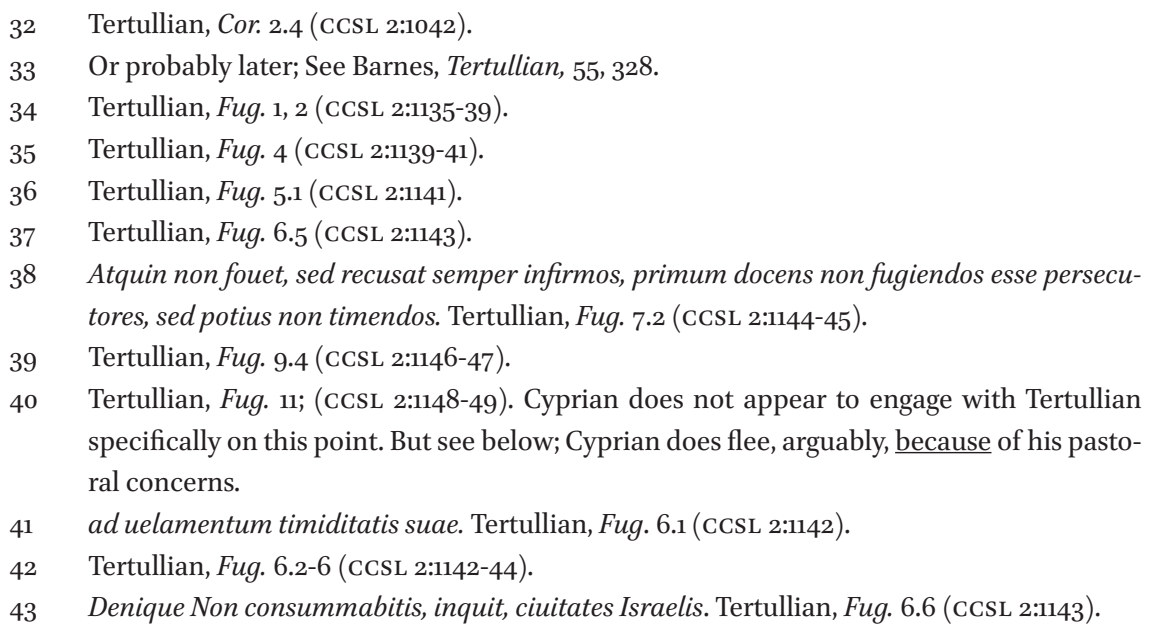


commission to preach the gospel to all the world as one which followed after, when the word of God had been rejected by the Jews (quoting Acts 13:46).

If, therefore, the prohibition against setting foot in the way of the Gentiles, and entering into the cities of the Samaritans, has come to an end, why should not the command to flee, which was issued at the same time, have come also to an end? Accordingly, from the time when, Israel having had its full measure, the apostles went over to the Gentiles, they neither fled from city to city, nor hesitated to suffer. ${ }^{44}$

There is some inconsistency in Tertullian's exegesis. Verse 17 not only refers to Jewish councils and synagogues, but the next verse predicts, "and you will be dragged before governors and kings for my sake, to bear witness before them and the Gentiles." In Scorpiace 11,Tertullian distinctly applied this whole section both to the apostles and to later Christians. The apostles clearly were brought before Gentile rulers (e.g., Paul in Acts 23-26). This is not the only contradiction in Tertullian's writings. ${ }^{45}$

Tertullian viewed flight as, at best, a poor alternative to standing firm and at worst, as apostasy. He did not acknowledge that flight itself can be suffering, as Cyprian did. ${ }^{46}$ The argument that flight would enable a Christian, particularly a cleric, to continue the work of witness and pastoral care carried little weight with Tertullian; he reserved that provision solely for Jesus and the apostles. ${ }^{47}$ Furthermore, Tertullian was convinced that flight in persecution was due to weakness, fear and cowardice. ${ }^{48}$ The fearful are among the castaways, who have their part in the lake of fire (Rev 21:8). ${ }^{49}$ Paul's escape in a basket from Damascus was a submission to a divine injunction, which ended when Paul

44 Si ergo cessauit exceptio uiae natiorum et introitus in ciuitates Samaritanorum, cur non cessaerit et fugae praeceptum pariter emissum? Denique ex quo saturato Israele apostoli in nationes transierunt, nec fugerunt de ciuitate in ciuitatem nec pati dubitauerunt. Tertullian, Fug. 6.8 (CCSL 2:1143).

For example, in Paen 8 (CCSL 1:308-9) Tertullian used the parables of the lost coin, sheep and son to prove God's willingness to pardon penitent Christians. In Pud 7 and 8 (CCSL 2:1292-96) he was adamant that these parables cannot apply to sinning Christians, but must only apply to the first repentance of the heathen.

46 Tertullian, Pat. 13.6 (CCSL 2:1144-45) is the notable exception.

47 Tertullian, Fug. 6.7, 8.1-2 (CCSL 2:1144-45).

48 Tertullian, Scorp. 1.5 (CCSL 2:1069-70).

49 Tertullian, Scorp. 12 (CCSL 2:1092-94), Fug. 9.3 (CCSL 2:1146). In Fug. 7.2 (CCSL 2: 1145) he wrote that regarding flight as a haven for the weak would be turpi et indigno et seruili. 
resolved to go to Jerusalem. ${ }^{50}$ To the one who flees from fear of apostasising, Tertullian replied with scorn, "Are you sure you will deny if you do not flee, or are you not sure? For if you are sure, you have denied already!"51

Tertullian's attitude to fleeing does appear to become more rigorous over time; ${ }^{52}$ he grudgingly accepted it in De Patientia and Ad Uxorem (c198-203), denigrated it in Scorpiace (203/4) and rejected it in De Corona and De Fuga $(208$ or later). Since we know very little about Tertullian's life, any influence of situational change is conjectural, although in De Fuga he intimated that imminent escalation of persecution had pressed the subject upon him. ${ }^{53}$

The traditional assumption that Tertullian became a Montanist around $206^{54}$ has been replaced with a consensus that Tertullian was influenced by Montanist literature ${ }^{55}$ but was not a schismatic Montanist. ${ }^{56}$ The supposition that Montanists, as opposed to "orthodox Christians," were vigorous voluntary mar-

$5^{0} \quad$ Tertullian, Fug. 6.9-6.11 (CCSL 1143-44). This interpretation is not borne out by the actual wording of either Ac 21:12-14 or 2 Co 11:30-33, yet Tertullian cites it as the proof of his thesis that the command to flee in Mt 10:23 was temporary. Nevertheless Cyprian claimed divine injunction for his own withdrawal.

certus es te negaturum, si non fugeris, an incertus? Si enim certus, iam negasti. Tertullian, Fug. 5.1 (2:1141).

For example, Robert Mooney's MA thesis, Tertullian's Ideal Christian: The Ideals of Persecution and Martyrdom in the True Christian Life, Alberta, 2014, pp. 83-84 <https://era.library. ualberta.ca/files/5425kd50z\#.WptFonyYPIU> accessed 24/2/18. Mooney's point is that Tertullian's picture of the true Christian embodied a duty of martyrdom but that real world Christians fell short, but the strength to fulfil this picture comes from the Holy Spirit, a perspective inspired by Montanism.

53 Tertullian, Fug 1.1 (ccsL 2:1135).

54 Barnes, for example, takes the position that Montanism was very successful in Carthage and that Tertullian recognised the validity of the New Prophecy, resulting in a restoration rather than a genuine innovation in theology, Barnes, Tertullian, pp. 131-2, 140. Wilhite hints that Montanism, like Marcionism, may have had a smaller presence in North Africa than is often assumed, David E Wilhite, "Marcionites in Africa: What did Tertullian know and when did he invent it?" Perspectives in Religious Studies, 43:4, (2016), pp. 437-452, p. 440.

For example, the Montanist oracle reproduced in Tertullian, Fug 9.4 (CCSL 2:1147), but see Wilhite, "Marcionites in Africa, p. 443 and David E. Wilhite, "The Spirit of Prophecy: Tertullian's Pauline Pneumatology," in David E. Wilhite and Todd D. Still, eds., Pauline and Patristic Scholars in Debate, Vol 1: Tertullian and Paul, New York, 2013, p. 46 for the argument that citation does not equate with belonging.

56 Wilhite, "Spirit of Prophecy," pp. 45-46; and see the whole essay for an analysis of perspectives on Tertullian's "Montanism." 
tyrs $^{57}$ has been refuted, ${ }^{58}$ along with a convenient justification for Tertullian's later delegitimisation of flight. ${ }^{59}$ Voluntary martyrdom was not exclusively "heretical," but part of the normal spectrum of "orthodoxy." ${ }^{\circ 0}$ Furthermore, the equation of Tertullian's references to the Paraclete, spiritual inspiration or (new) prophecy with Montanist theology overlooks the influence of prophecy, visions and the influence of the Spirit on the third century African church.$^{61}$ As Wilhite notes, more work needs to be done to recognise Tertullian's consistency and independence of thought in both his "pre-Montanist" and "Montanist" periods. ${ }^{62}$

Nevertheless, Tertullian saw the Paraclete as essential for enabling Christians to embrace martyrdom, rather than flee from cowardice. ${ }^{63}$ If he was blinkered, it was to the possibility that the Spirit might also direct a Christian to flee, as Cyprian asserted. Moss observes that Tertullian initially attributed persecution to the devil's deception, but later saw it as originating in the will of God, and therefore good. ${ }^{64}$ Nevertheless, Tertullian consistently exalted mar-

57 Barnes, Tertullian, p. 167 asserts that in threatening Scapula with the prospect of thousands of Christian martyrs, "Tertullian represents every Christian in Carthage as being a Montanist."

$5^{8}$ Candida Moss, "Justification of the Martyrs," in David E. Wilhite and Todd D. Still, eds., Pauline and Patristic Scholars in Debate, Vol 1: Tertullian and Paul, New York, 2013, p. 117. See also William Tabbernee, "Early Montanism and Voluntary Martyrdom," Colloquium, 17:2, (1985), pp. 33-44.

59 So Barnes, Tertullian, p. 177-8; "After his conversion [to Montanism] Tertullian was soon deriding the views he had once shared." Although Barnes, in his early work, clearly asserted Tertullian to be a Montanist, he also argues that Tertullian's arguments were "independent of his Montanist convictions" but rooted in his broader theology of God, evil and providence ( $\mathrm{p}$ 183). Barnes later corrects his position on Tertullian's theological development in his 2005 edition, regarding his chapter on Montanism as relatively weak, and failing to bring out how Tertullian's views "both cohere and change" with respect to the choices confronting Christians of his day (p. 331).

6o $\quad$ Middleton, Radical Martyrdom, pp. 23-25, 38-39.

$61 \quad$ Wilhite, "Spirit of Prophecy," p. 47. Wilhite argues that Tertullian's understanding of the Holy Spirit is "thoroughly Pauline," ibid., p. 46. Cyprian allegedly withdrew by divine command, and he has not been labelled Montanist.

62 Wilhite, "Spirit of Prophecy," p. 48. Similarly, Moss, "Justification of the Martyrs," p. 106, observes the likelihood of Tertullian's pre-Montanist views having little distinction from his later "Montanist" views.

63 Tertullian, Fug 14.3 (CCSL 2:1155). So Moss, "Justification of the Martyrs," p. 106.

64 Moss, "Justification of the Martyrs," pp. 114-117. 
tyrdom. ${ }^{65}$ God provided, against post-baptismal sin, the "last means of succour, the fight of martyrdom and the baptism of blood, thereafter free from danger."66 To flee is to imperil one's salvation because it is a denial, not an imitation, of Christ. God demands of his saints "in martyrdom that death which he exacted even of his Christ." ${ }^{67}$ Martyrdom is a means to "buy back the whole favour of God,"68 procuring indulgence by the payment of one's own blood. "For all sins are forgiven to this action... when we are condemned by you [the Romans] we are acquitted by God." ${ }^{\prime 9}$ The greater the conflict and suffering, the greater the reward. ${ }^{70}$ Martyrdom alone will ensure immediate transport to Paradise. ${ }^{71}$

But must we necessarily look to a change in Tertullian's theology as an explanation for his dealings with Mt 10:23? Tertullian was an accomplished rhetor, writing not as an exegete, but as a polemicist. Putting it bluntly, Tertullian would do whatever it took to win an argument. ${ }^{72} \mathrm{He}$ adopted rhetorical strategies designed to convince his hearer/reader that his position was correct and his opponent's was not. ${ }^{73}$ In so doing, he could act for either the defence or the prosecution. ${ }^{74}$ Dunn convincingly demonstrates Tertullian's inconsis-

65 For a thorough review of Tertullian's perspective of conflict, see Eric Osborn, Tertullian, First Theologian of the West, Cambridge, 1997, pp. 225-258.

66 Posuit igitur secunda solacia et extrema praesidia, dimicationem martyrii et lauacrum sanguinis exinde secuturum. Tertullian, Scorp. 6.9 (CCSL 2:1080).

67 mortem per martyrium quoque flagitantis, quam de Christo etiam suo exegit. Tertullian, An. 50.4 (CCSL 2:856).

68 totam Dei gratiam redimat. Tertullian, Apol. 50.15 (CCSL 1:171).

69 Omnia enim huic operi delicta donantur... cum damnamur a uobis, a Deo absoluimur. Tertullian, Apol. 50. 16 (CCSL 1:171).

$70 \quad$ Tertullian, Scorp. 6 (CCSL 2:1079-81), Scap. 4 (CCSL 2:1130-31), Res. 8 (CCSL 2:931-32).

71 Tertullian, Res. 43 (CCSL 2:978-79), An. 55.4 (CCSL 2:862-63).

72 "Tertullian would support whatever method of using the Scriptures would win his argument for him." Geoffrey D. Dunn, Tertullian, London, 2004, p. 23.

73 Wilhite, "Marcionites in Africa," pp. 437-8; 445 asserts that Tertullian used rhetorical tactics "mercilessly" and it can be a struggle to differentiate his rhetoric from his actual teachings. What was important was that the argument convinced. He further notes that Tertullian's rhetoric may both reveal and obfuscate his theology; David E Wilhite, "Rhetoric and Theology in Tertullian: What Tertullian Learned from Paul," Studia Patristica 54 (2012), pp. 295-312, p. 295.

74 Geoffrey D. Dunn, "Tertullian's Scriptural Exegesis on de paescriptine haerticorum," Journal of Early Christian Studies, 14.2, pp. 141-155; "Tertullian knew how to argue in favour of one method of interpreting the Scriptures in one instance and how to argue for exactly the opposite in another" p. 142; "Classical forensic rhetoric taught orators how to argue for and against a particular matter depending on their position as prosecutor or defender... 
tent hermeneutical methods and use of historical context; Tertullian's theological points about scriptural exegesis were "situational and relative."75 De Patientia was a positive defence of patience, applicable to flight as well as imprisonment, punishments and death. ${ }^{76}$ It would be adverse to his overall exaltation of patience to argue against flight, so he allowed it. In Ad Uxorem, Mt 10:23 supported his argument that something can be permitted, although not ideal; it served as a paradigm. Scorpiace was a polemic against heretics who avoided and denounced martyrdom, so he quietly sidestepped the verse which did not serve, and potentially clouded, his argument. De Corona was a polemic against the faithful soldier's detractors, who were fearful of attention and martyrdom, so their recourse to Mt 10:23 must be scornfully derided. De Fuga was a polemical response to those who would promote flight in persecution as a way to escape martyrdom. In it Tertullian systematically demolished multiple pro-flight arguments, his opponents' exegesis of Matt 10:23 being only one. $\mathrm{He}$ could not ignore it, nor could he oppose Jesus' words, so his strategy was to refute its contemporary application. ${ }^{77}$ Appeal to context was critical to Tertullian's exegesis of Mt 10:23; the key issue was whether the missionary discourse, and hence the command to flee, was limited to the Twelve's pre-Easter commission or had ongoing applicability. Dunn discusses a similar example with Tertullian's use of Mt 7:7 in De Praescriptione; he restricted the verse's application to the original audience (even though this would, by extension, so limit the whole sermon on the mount) whereas the heretics had universalised it. ${ }^{78}$

I suggest that the primary influence on Tertullian's use of Matthew 10:23 was rhetorical, and his varied exegesis and application of it was determined by its

No one would expect a forensic orator to hold the same position in every case he or she argued" p. 153 .

75 Dunn, “Tertullian's Scriptural Exegesis”, p. 146.

76 Tertullian, Pat 13.6 (CCSL 1:314).

77 Wilhite, "What Tertullian Learned from Paul," p. 309. For a discussion of Tertullian's appeal to the Pauline scriptures in De Fuga, see Todd D. Still, "Martyrdom as Sacrament: Tertullian's (mis)use of 'the Apostle' (Paul)," in David E. Wilhite and Todd D. Still, eds., Pauline and Patristic Scholars in Debate, Vol 1: Tertullian and Paul, New York, 2013, pp. 1234. Wilhite demonstrates that Tertullian, like Paul, would counter an opponent's prooftexting by appeal to the context of the passage.

78 Dunn, “Tertullian's Scriptural Exegesis", p. 149. "It therefore suited his purpose to counter their position with his argument of historical context as an interpretive principle... while it suited his purpose in this particular debate, it would not always be so appropriate in every instance." The parallel situation in Mt 10 is that Tertullian had to confine the whole missionary discourse to the original Twelve in order to so restrict verse 23, in contrast to his exegetical argument in Scorpiace. 
role in his broader argument in each case. This does not mean that such usage is entirely independent of his situation and his evolving theology, however. If, for Tertullian, the yardstick of genuine Christianity was the authoritative interpretation of Scripture according to the apostolic regula fide, ${ }^{79}$ a later distinction between the "psychic" church and the "church of the Paraclete" may have altered his concept of the "correct" exegesis of Mt 10:23. Anticipation of increased persecution, a modified view of the origin of persecution, and perhaps a more rigorist (Montanist?) position, would have steered him into the different sorts of arguments which he addressed in his later works, for which different rhetorical strategies were required.

I propose that Tertullian's actual perspective on flight in persecution changed little. He regarded it as a poor choice for a Christian, whose highest calling was to die for his Lord. Amplifying or toning down that position to suit the argument at hand constituted rhetorical strategy. Intriguingly, despite Tertullian's presumably high profile in Carthage, and his references to present and imminent persecution, there is no record of him ever confessing, being imprisoned, tortured or martyred for his faith. Was this providential? Or did he, for some unspoken reason, keep a low profile? ${ }^{80}$ Arguably, not all flight was motivated by fear, an accusation that falters with Origen and, ultimately, Cyprian. As Dunn observes, it is difficult to generalise as to what Tertullian actually "believed." Perhaps De Fuga misrepresents his personal position on flight, especially given that the one thing he never explains is how and why he himself was not brought to glorious confession.

\section{Clement of Alexandria}

Of Clement's extant works, only the Stromateis, particularly Book $4,{ }^{81}$ have a direct bearing on the topic of persecution. Clement's "gnostic" Christian was prepared for death:

79 Dunn, “Tertullian's Scriptural Exegesis," p. 146.

80 Barnes, Tertullian, p. 176, citing Scorp 1.11 (CCSL 2"1071), tentatively implies Tertullian's flight from his apparent self-inclusion in the hares being pursued. Nos ipsi ut lepores destinata uenatio... I don't believe Tertullian was himself fleeing here, but rhetorically contrasted "us" Christians, who are pursued with "heretics," who are not.

81

Eusebius, H.E., 6.6. Eusebius does not specify whether this was before, during or after the Severan persecution, 202-3. Paul L. Maier, trans. Eusebius: The Church History, Grand Rapids, 2007. However, book 1 of the Stromateis has been dated to c 198: Heine places Clement's flight from Alexandria during the Severan persecution 202-3 and his subsequent 
The severance, therefore, of the soul from the body, made a life-long study, produces in the philosopher gnostic alacrity, so that he is easily able to bear natural death, which is the dissolution of the chains which bind the soul to the body. ${ }^{82}$

For Clement, martyrdom was an appropriate completion of the gnostic life and an occasion for witness. ${ }^{83}$ Persecution may be unjust, and its perpetrators judged, but no wrong is actually being done to the Christian because martyrdom is the gateway to eternal life. ${ }^{84}$ Little is known about Clement's life, but evidently, at the time of his flight, Clement was not quite ready to dissolve his soul's chains. Mullins-Reaves suggests that Clement's preference for gnostic martyrdom in the whole of life aligns with his prioritisation of individual rather than communal expressions of identity. ${ }^{85}$ I concur that this allowed Clement to be equally satisfied with martyrdom or with survival. Martyrdom was a good thing, but it wasn't the only good thing. Clement identified the source of evil in the abuse of human and angelic free will. Floyd attributes this partly to an anti-Gnostic polemic and partly to his Platonist background. ${ }^{86}$ Osborne acknowledges the challenge of Gnostic dualism and determinism for Clement's theology, but sees the experience of persecution as also influential. ${ }^{87}$ Christians were challenged as to why a God who supposedly cared for them allowed persecution. ${ }^{88}$ Clement's answer was that God does not cause evil, but allows it to happen in the exercise of free will. God's genius is in the good that he brings from this evil. Persecution comes by the sin and injustice of the persecu-

death in exile sometime before 215. Ronald E. Heine, "The Alexandrians," in Frances Young, Lewis Ayres and Andrew Louth, eds., The Cambridge History of Early Christian Literature, Cambridge, 2004, p. 117-118.

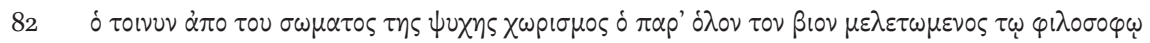

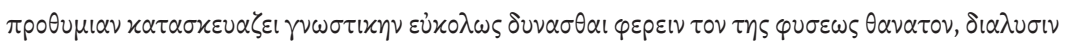

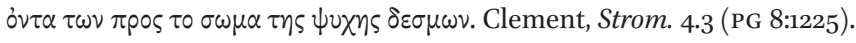

83 Clement, Strom. 4.6 (PG 8:1237-53).

84 Clement, Strom 4.11 (PG 8:1288-89) - a point with which Tertullian concurred, e.g., Scap. 1.1 (CCSL 2:1127).

85 Pamela Mullins-Reaves, "Multiple Martyrdoms and Christian Identity in Clement of Alexandria's Stromateis," Studia Patristica 66 (2013), pp. 61-68.

86 W.E.G. Floyd, Clement of Alexandria's Treatment of the Problem of Evil, Oxford, 1971, summarised pp. xviii-xxi.

87 E.F. Osborn, The Philosophy of Clement of Alexandria, Cambridge, 1957, pp. 65-83, 70.

88 Clement, Strom. 4.11 (PG 8:1288). 
tors for the purpose of Christian sanctification through suffering. ${ }^{89}$ Thus Clement saw martyrdom as a good, since it brings perfection and blessing. ${ }^{90}$

In Stromata 4.4, Clement discussed three approaches to martyrdom. ${ }^{91}$ Some heretics had "an impious and cowardly love of life." ${ }^{22}$ Whilst Clement agreed that true martyrdom is the knowledge of the only true God, he rejected their conclusion that "the man is a self-murderer and a suicide who makes confession by death." ${ }^{93}$ Nevertheless, Clement did not support the other extreme, "rushing on death. ${ }^{94} \mathrm{He}$ argued that it is by the path of life and health that we learn gnosis and it is not wrong to live well, there being more than one secure path to immortality. Tertullian assumed that confession at trial was God's will. Clement believed that God alone chooses the martyr and we should not preempt or assume that. ${ }^{95}$ Clement, contra Tertullian, denied that persecution comes directly from God. Alluding to Mt 10:22, Clement denied that God delivers his people to persecution or calamity. Rather, he has foretold prophetically that we would be persecuted for his name's sake. ${ }^{96}$

Clement equated confession of Christ before men explicitly with martyrdom. But those who confess by life and word are better than those who confess by word alone. Everyone must confess, but it is not given to all to make confession at trial. Confession is within our power, but to be brought to trial is not. Nevertheless, it can be valid to make a sudden verbal confession at the end of life; "the cleansing away of sins with glory." ${ }^{\text {" } 7 ~ W h e n ~ J e s u s ~ t o l d ~ t h e ~ d i s c i p l e s ~ i n ~}$ Mt 10:23 to flee to another city, he was not denigrating persecution as an evil thing, nor asking them to avoid death. Rather, he wants us to avoid being the

89 Osborne, Philosophy of Clement, pp. 71-76.

90 Clement, Strom. 4.4; 4.6 (PG 8:1225-32, 1237-53).

$91 \quad$ Against the traditional "spectrum" of Voluntary martyr ("bad") - Clement's middle way ("orthodox") - Gnostic rejection of martyrdom ("bad") ascribed to Clement, Mullins Reaves, "Multiple Martyrdoms," argues that Clement's tiered conception of martyrdom aligns with his individual rather than a communal expression of Christian identity. $\dot{\alpha} \sigma \varepsilon \beta \omega \varsigma \dot{\alpha} \mu \alpha \alpha \alpha \mathrm{l} \delta \varepsilon 1 \lambda \omega \varsigma \varphi 1 \lambda 0 \zeta \omega 0 v \sigma l$. Clement, Strom. 4.4 (PG 8:1229).

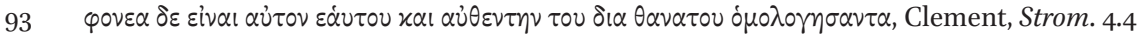
(PG 8:1229). The Gnostics have generally been identified as being anti-martyrdom and thus the heretics of whom Clement wrote. This has been challenged by Philip L. Tite, "Voluntary Martyrdom and Gnosticism," Journal of Early Christian Studies, 23:1, (2015), pp. 27-54.

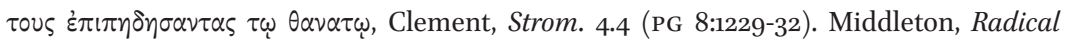
Martyrdom, p. 24, does not think that Clement is discussing orthodox Christians here, many of whom were voluntary martyrs, but rather heretics who disparage the body. Clement, Strom, 4.9 (PG 8:1280-85).

96 Clement, Strom. 4.11 (PG 8:1288).

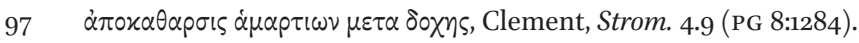


authors or abettors of evil, either to ourselves or to the persecutors and murderers. ${ }^{98}$ Tertullian put the onus on the persecutors, who will not escape the day of judgement, ${ }^{99}$ warning them not to fight against God. ${ }^{100}$ But Clement maintained that Jesus bids us take care of ourselves. He who presents himself before the judgement seat becomes guilty of his own death, likewise the one who does not avoid persecution but out of daring presents himself for capture. ${ }^{101}$ The judge who condemns Christians has free will and will himself be judged. No wrong is being done to Christians by releasing them in death to be with the Lord, but provocation and presenting oneself for capture make one an accomplice and bring guilt. For this reason, Clement could advocate flight as an appropriate alternative to provocation. He who is truly brave courageously awaits what comes. Those who protect themselves reasonably, when God really calls them, surrender themselves. ${ }^{102}$

Clement's so-called "middle way" prompted categorisation or scaled responses to persecution ${ }^{103}$ which have rightly been challenged. ${ }^{104}$ Such categories, while somewhat helpful, are artificial and do not accommodate flight. With respect to Clement's thoughts on martyrdom and flight, we need only understand his theology of "gnostic" life to understand his interpretation of Matthew 10:23.

\footnotetext{
98 Clement, Strom. 4.10 (PG 8:1285-88).

99 Tertullian, Scap. 3.1, 3.5 (CCSL 2:1129-30).

$100 \quad$ Tertullian, Scap. 4.1, 5.3 (CCSL 2:1130, 32).

101 The more extreme form of "voluntary" martyrdom, ascribed to Quintus in Polycarp, and to Agathonice and as criticised by Lucian, which Middleton, Radical Martyrdom, pp. 25-37, argues was more widespread and acceptable than often credited.

102 Clement, Strom. 7.11 (PG 8:492).

103 For example, G.E.M. de Ste Croix, "Voluntary Martyrdom in the Early Church," in: Christian Persecution, Martyrdom and Orthodoxy, ed. Whitby, Michael and Streeter, Joseph. Oxford, 2006, pp. 153-154, further subdivides martyrs into "Voluntary martyrs" (who explicitly demand martyrdom, come forward in times of persecution or provoke arrest and execution by a deliberate act); "quasi-volunteers" (exceptional rigorists, attentionattractors and the deliberate contumacists) "religious suicides" (eg to protect their chastity) and "ordinary martyrs." This categorising and second-guessing of motivation has been challenged by Oliver Nicholson, "What Makes a Voluntary Martyr?" Studia Patristica 65 (2013), pp. 159-164.

104 Nicholson, “What Makes a Voluntary Martyr?" pp. 159-164.
} 


\section{Origen of Alexandria}

Origen also valued martyrdom. "The powers of evil suffer defeat by the death of the holy martyrs," producing benefit for others. ${ }^{105}$ It is cause for rejoicing that we are worthy to suffer shame for Christ's name. ${ }^{106}$ Martyrdom is a sacrifice, like that of Christ, and foreshadowed by the sacrifices of the Law. ${ }^{107}$ It is a way for someone to give back something to God for what he has done for them; "he finds that nothing else can be given to God... that will so balance his benefits as perfection in martyrdom."108 Like a second baptism, martyrdom brings forgiveness of sins. ${ }^{109}$ It is an exaltation, by which we glorify God. ${ }^{110}$ Christians must hold fast in persecution; the greater the struggle the more worthy the recipient of the prize. ${ }^{111}$

Despite his initial, thwarted, desire to join his father in martyrdom, ${ }^{112}$ Origen twice moved away to preserve his life before finally submitting to imprisonment and torture as an old man. ${ }^{113}$ Evidently not afraid to suffer and die, nevertheless his writings demonstrate a belief that martyrdom should not be courted. Christians should escape confrontation with the authorities if possible, if this can be done without recanting, for it saves them from committing a crime. ${ }^{114}$ Origen's interpretation of the scriptural sanction for flight was informed by his theology of providence and of love. ${ }^{115}$ Rankin suggests that Ori-

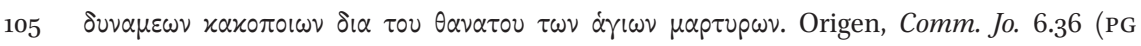
14:293).

106 Mt 5:10-12; Lk 6:23; Ac 5:41; Origen, Mart 4 (PG 11:568).

107 Origen, Comm. Jo. 6.36 (PG 14:293).

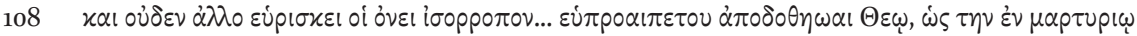
$\tau \varepsilon \lambda \varepsilon \cup \tau \eta \nu . ~ O r i g e n$, Mart. 28 PG 11:596).

109 Origen, Mart. 30 (PG 11:60o-601) so also Tertullian, and Cyprian.

110 Origen, Mart. 50 (PG 11:635).

111 Origen, Princ. 2.9.7 (PG 11:231-232). In fact, he suggested a sort of meritorious hierarchy among martyrs, depending how much they suffered and what they had given up; Mart. 15 (PG 11:582-83).

112 Eusebius, H.E., 6.1, recounts that he would have joined Leonides, but his mother hid his clothes. Had young Origen followed his father, the church would have been greatly deprived.

113 Heine, "The Alexandrians," pp. 121-122, notes Origen left Alexandria in 232 due to conflict with bishop Demetrius, went into hiding during the 235-8 local persecution under Maximinus Thrax (when he wrote Exhortation to Martyrdom) and was tortured in the Decian persecution of 250 , later dying in the reign of Gallus, presumably from the injuries received.

114 Origen, Comm.Jo. 28.18 (PG 14:728-32).

115 For general background on Origen's interpretation of Scripture, see Henri Crouzel, trans.
} 
gen espoused a form of Christian pacifism, whereby Christians seek the higher good, viewing the empire in terms of divine providence. ${ }^{116}$

Origen maintained that Matthew 10, including the instruction to flee when persecuted, was directed to the apostles specifically. Nevertheless, the exhortation to martyrdom, should be heard by us, "since by hearing it we shall be brothers of the apostles who heard it and shall be numbered with the apostles."117 In applying Mt 10:28-33 to Jesus' friends in a broader sense, ${ }^{118}$ Origen considered that 10:23 also applied beyond the apostles, in keeping with his exegetical premise that all Scripture is not only Christocentric but has application to the Christian life.

Origen rebutted Celsus' criticism, based on Mt 10:23, that Jesus led a miserable life in hiding through fear."19 "It is not dishonourable to avoid exposing oneself to dangers, but to guard carefully against them, when this is done, not through fear of death, but from a desire to benefit others by remaining in life until the proper time."120 Origen countered that "it became him who was making provision for his sojourning in the world as a human being, not to expose himself unseasonably to the danger of death." ${ }^{121}$ Jesus was not at the mercy of circumstance, "for at the appropriate time he allowed himself to fall into the hands of men, as the Lamb of God."122 This explanation is rooted in Origen's understanding of providence: all that happens is sent by God, and that all occurrences in the world are brought about "not indeed by God, and yet not without him." ${ }^{123}$ God does not prohibit wicked and opposing powers

A.S. Worrall, Origen, San Francisco (date) pp. 61-84; Peter W. Martens, Origen and Scripture: The Contours of the Exegetical Life, Oxford (date); Young, Biblical Exegesis, pp. 21-27.

116 David Rankin, From Clement to Origen: The Social and Historical Context of the Church Fathers, Hampshire, 2006 pp. 138-39.

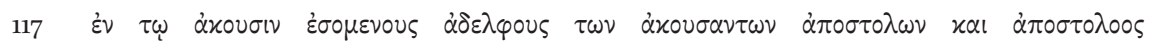

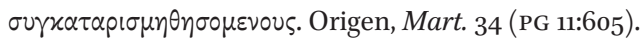

118 Origen, Mart. 35 (PG 11:609).

119 Origen, Cels. 1.65 (PG 11:781). Such incidents in Jesus' life as recorded in Mt 2:13-14; Lk 4:2930 and Jn 8:59 were apparently used by some Christians to justify flight in persecution; a usage which Tertullian also challenged; Fug. 8:1-2 (CCSL 2:1146).

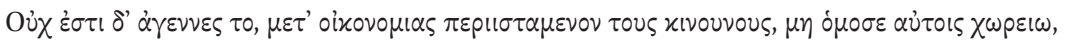

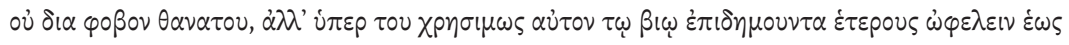

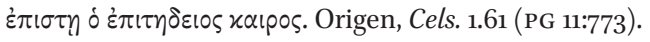

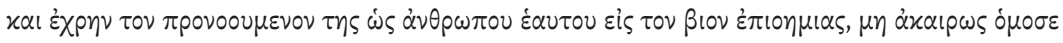

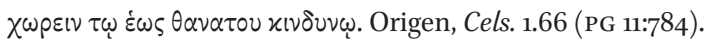

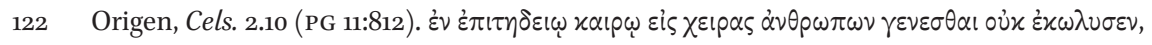

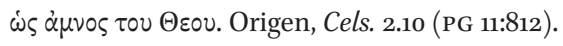

123 Origen, Princ. 3.2.7 (PG 11:313). non quidem a Deo fiunt, nec tamen sine Deo. Origen, Princ. 3.2.7 (PG 11:313). 
from accomplishing their purposes, but rather permits them. ${ }^{124}$ Citing Mt 10: 28-33, he asserted that "the Lord teaches us that no one comes to the contest of martyrdom without providence."125 Origen admitted of corporal and external evils, and that there are occasions when these have been called into existence by God in order to effect the conversion of individuals. God converts and cures men using sufferings. ${ }^{126}$ God delivers us from evil, not when the enemy does not engage us at all, but when we stand and are victorious; God delivers us from afflictions when, by his help, we are not straightened under them. ${ }^{127}$ All things work together for heavenly, not earthly benefits. ${ }^{128}$

Origen discussed Jesus' withdrawal to a desert place after hearing of John the Baptist's murder, citing Mt 10:23.

The letter ${ }^{129}$ teaches us to withdraw as far as it is in our power from those who persecute us, and from expected conspiracies through words; for this would be to act according to prudence; and, when one can keep outside of critical positions, to go to meet them is rash and headstrong. For who would still hesitate about avoiding such things, when not only did Jesus retreat in view of what happened to John, but also taught and said, If they persecute you in this city, flee ye into the other? When a temptation comes which is not in our power to avoid, we must endure it with exceeding nobleness and courage; but, when it is in our power to avoid it, not to do so is rash. ${ }^{130}$

124 Origen, Princ. 3.2.7 (PG 11:313).

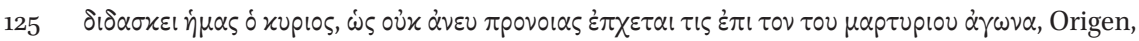
Mart. 3 (PG 11:608). Origen's position on providence was therefore similar, but not identical to, that of Tertullian, who asserted that persecution is the will of God and comes from God and is therefore good; only the injustice of it is of the devil which is in turn subject to God; Tertullian, Fug. 2 (CCsL 2:1138-39).

126 Origen, Cels. 6.56 (PG 11:1384-85).

127 Origen, Or. 30 (PG 11:545).

128 Origen, Philoc. 24, treatise on Psalm 4 (PG 2:1163-65).

129 The "literal" or surface meaning. Here Origen does not need to appeal to allegory to counter Celsus. For an overview of Origen's interpretation of Scripture, see Stephen Westerholm and Martin Westerholm, Reading Sacred Scripture: Voices from the History of Biblical Interpretation, Grand Rapids, 2016, pp. 67-100. For foundational studies on Origen's exegesis, see R.P.C Hanson, Allegory and Event: A study of the sources and significance of Origen's interpretation of Scripture, London, 1959 and Henri Crouzel, Origen, trans. A.S. Worral, SanFransico, 1989 .

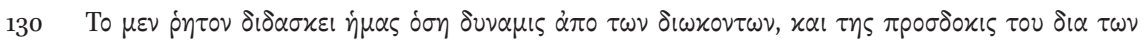

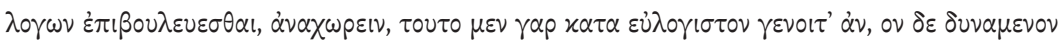

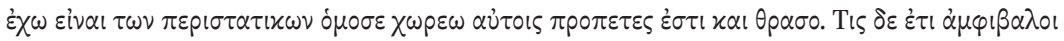


This is in keeping with the idea that flight for the purpose of preserving oneself for God's work is legitimate and appropriate. Such flight from punishment, "is not from cowardice, but in obedience to the command of his Master (presumably Mt 10:23) so that he may preserve himself, and employ his strength for the benefit of others." 131 Origen's exegesis of the "literal" meaning of Jn 11:54 demonstrates that Christ's withdrawal was recorded specifically because "the Word wishes to turn us back from rushing too hastily and too irrationally to struggle unto death on behalf of the truth and to suffer martyrdom." ${ }^{132}$ It is right, he contended, to not shun confession nor hesitate to die for the truth if caught in the struggle, however it is also appropriate to avoid such a trial by every means, because we don't know the outcome and would be responsible for the guilt of bloodshed. ${ }^{133}$

Origen believed it would even be self-centred and inconsiderate of others to deliver ourselves unnecessarily to be killed! In contrast, Tertullian put the onus on the persecutor, with all advantage to the Christian. ${ }^{134}$ Clement and Origen acknowledged that Jesus' complete control over his arrest and death, and his prior withdrawal was prudent. ${ }^{135}$ For this reason, claimed Origen, we must heed the words "If they persecute you in this city, flee to another."136 In the same way that Jesus taught us to withdraw in persecution, he also taught us to flee honours and positions of superiority in the world. ${ }^{137}$ Kolbet rightly ob-

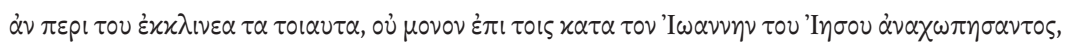

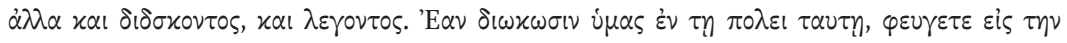

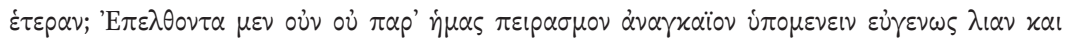

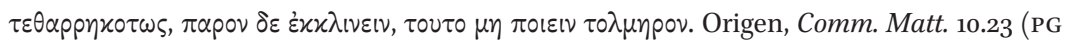
3:897).

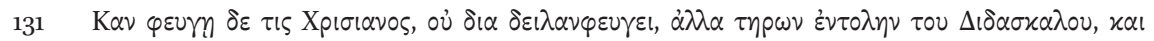

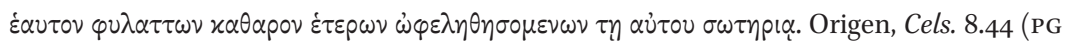
11:1584).

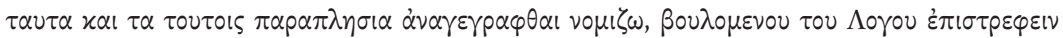

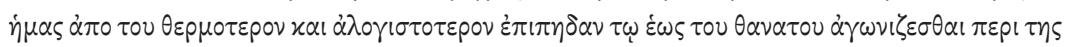

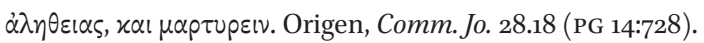

133 Origen, Comm. Jo. 28.18 (PG 14:728-29). This was also Clement's argument.

134 Tertullian, Scap. 1, 5 (CCSL 2:1127, 1131-32). Geoffrey D. Dunn, "Rhetorical Structure in Tertullian's Ad Scapulam," Vigilae Christianae 56 (2002) pp. 47-55 argues that, given the futility of the Roman policy of persecution, it should cease, and appeals not to Scapula's sense of honour, but his fear of dire consequences in failing to maintain peace and stability. The Christians would be willing to "force the issue" by presenting themselves for slaughter (p. 54).

135 Origen, Comm.Jo. 28.18 (PG 14:729)

136 Origen, Comm.Jo. 28.18 (PG 14:729) quoting Mt 10:23

137 Origen, Comm.Jo. 28.18 (PG 14.732) 
serves that Origen's concern for persecutors contrasts with the purpose of torture and persecution, which are exercises in terror, to make the tortured a public testimonial to the ideology of the subjugating power. Perpetrators of torture must devalue their victims, see them as other, dehumanise them, whereas Origen embraced an intentional discipline of loving one's enemies. ${ }^{138}$ Although Tertullian stated that Christians alone love those who hate them and pray for their persecutors, Christians, for whom Roman cruelty is glory, both welcome and seek martyrdom. ${ }^{139}$ The same concern for persecutors provoked significantly different responses in Tertullian and Origen. Overall, it was Origen's theological perspective and hermeneutic of non-violence that informed his exegesis of Mt 10:23.

\section{Cyprian of Carthage}

Cyprian, was criticised as a "bad shepherd" for his "retirement" in the Decian persecution, yet his unflinching dedication to his role as shepherd under changing circumstances accounts for both his withdrawal and his ultimate confession. Tertullian had scathingly denounced pastors who abandoned their flock; such were the bad shepherds with whom Christ contrasted himself in John 10:11-15. ${ }^{140}$ The same accusation of abandonment of the flock came in the Roman clergy's letter. ${ }^{141}$ Cyprian formulated Christian unity around the bishopric, and saw himself first and foremost as the bishop, God's representative to the people and the people's representative before God. ${ }^{142}$ To reject the bishop

138 Paul R. Kolbet, “Torture and Origen's Hermeneutics of Non-violence," Journal of the American Academy of Religion, 76.3 (2008), 545-572, p. 564.

139 Barnes, Tertullian, pp. 166-7, notes with some irony the thinly veiled threat which subsumed Tertullian's profession of concern, but perhaps overstates that Tertullian represents every Carthaginian Christian as a Montanist. Shockingly, at the close of De Spectaculis Tertullian delighted in the terrible retribution of the persecutors.

140 Tertullian, Fug 11 (CCSL 2:1148-49).

141 This is the not-so-subtle implication of $E p$ 8, and Cyprian seemed to periodically return to the shepherd-flock analogy, as if the accusation continued to sting. Noting this, Daniel Boyarin, Dying for God: Martyrdom and the Making of Christianity and Judaism, Sanford, 1999, p. 6o. Boyarin adds, "The only thing that justifies Cyprian's temporary evasion of martyrdom is the fact that in the end he was, like Peter, martyred." I find it inconsistent that Origen does not receive the same criticism. Boyarin does, however, find rabbinic parallels for Clement's “ambivalence” and Tertullian's “Maccabean” perspective p. 62.

142 G.W. Clarke, The Letters of St. Cyprian of Carthage, 4 vols., New York, 1984-1989, Vol. 1, p. 288. All English translations of Cyprian's letters are from this work. 
was to reject God's appointment. The basis of his episcopal authority was rooted in the Scriptures. ${ }^{143}$ Wilhite argues that Cyprian varied his use of scripture according to his readership, particularly in the context of Cyprian's social construction of those with him and those against him. ${ }^{144}$

Cyprian also recognised another form of authoritative communication from God, mediated by the Holy Spirit for whom the bishop was the conduit to the church. ${ }^{145}$ He claimed that God had sent two visions, blaming disunity for the tribulation of the church. ${ }^{146}$ Complaining of the rebel presbyters' overriding of his episcopal authority, Cyprian called to witness not only Scripture but night visions and ecstatic utterances prompted by the Holy Spirit, affirming that the Lord had bidden him to withdraw. ${ }^{147}$ Formally defending his actions as bishop, he attributed his withdrawal to following the directives and instruction of the Lord. ${ }^{148}$ In contrast, Tertullian was unable to envisage the Holy Spirit giving any other directive but that of martyrdom. ${ }^{149}$ Boyarin finds a parallel defence for Cyprian's withdrawal in that of Rabbi Yose in the Talmud; it is better for teachers of Torah to withdraw than be killed prematurely and cease doing the Lord's work. ${ }^{150}$

143 David E. Wilhite, “Cyprian's Scriptural Hermeneutic of Identity: The Laxist 'Heresy," Horizons in Biblical Theology, 32 (2010), pp. 58-98.

144 Wilhite, "Hermeneutic of Identity," pp. 67-71, 79-81. I find this similar to Tertullian's argument in Praescr. that the heretics have no right to use the scriptures, as they belong to true Christians. Wilhite here expands on and departs from, the work of Michael A. Fahey, Cyprian and the Bible: A Study in Third-Century Exegesis, Tubingen, 1971, on Cyprian's use of scripture. Wilhite's point is that the scripturally literate, who are addressed with bare scriptural quotations, are in agreement with the scriptures and the bishop's scriptural authority. The "Other" (laxist) party are scripturally "illiterate," rejecting the authority of scriptures and bishop, hence his quotations to them are accompanied by explanation.

145 Clarke, Letters, Vol. 1, p. 288 n.27 and p. 290 n.30.

146 E.p 11.3.1, 4.2, 5.1 (CCSL 3B:59-62) See Clarke, Letters, Vol. 1, n.21 and n.32, pp. $243-4$.

147 Ep. 16.4.1 (CCSL 3B:94) Clarke, n. 7, pp. 287-288, comments, "We may well be inclined to react unsympathetically to Cyprians exploitation of what appears to be unduly convenient heavenly illumination as knock-down argument in order to assert control over his turbulent clergy...But we ought at least to recall that this is written in a society where such inspiration was considered as a normal part of affairs." Also n. 30, p. 290, "This is no defensive remark about his retirement but a further assertion by Cyprian that he is under direct guidance from heaven."

148 Ep. 20.1.2 (CCSL 3B: 106-7). I believe this is too individual a claim to be an allusion to Mt 10:23.

149 Tertullian, Fug 9.4 (CCSL 2:1146-47).

150 Daniel Boyarin, Dying for God, p. 60. 
Cyprian withdrew from Carthage very early, before the full impact of the persecution. ${ }^{151}$ Given Cyprian's high view of the responsibilities of the bishopric and seeing other churches effectively decapitated, ${ }^{152}$ his withdrawal for the purposes he stated seems justified. ${ }^{153}$ Burns observes that honsetiores and "significant persons" such as Cyprian were more likely to be targeted by the edict to sacrifice. ${ }^{154}$ Exile and confiscation of property were imposed as punishment. Wealthy Christians could flee into voluntary exile or could purchase libelli. ${ }^{155}$ Cyprian effectively blamed the persecution on the Christians' love of comfort and wealth. ${ }^{156}$ Poorer Christian humiliores, including many of the lower clergy, had more hope escaping attention and ignoring the edict, unless betrayed. If they fled they would have been impoverished exiles, nor could they probably afford to purchase libelli. Cyprian required his clergy to stay and support the community in the bishop's absence. They appeared to be much less vulnerable than the Christian honestiores. ${ }^{157}$ Cyprian disapproved of the lower clergy, answerable to him, absenting themselves. ${ }^{158}$ This apparent hypocrisy is consistent with the social distinctions between the "classes" within the society of the church, under the bishop. ${ }^{159}$

Given Cyprian's prominence, his arrest was immediately demanded by the mob, which would have drawn negative attention to the whole Christian community, including the poorer Christians. Cyprian saw his primary responsibil-

151 J.Patout Burns Jr., Cyprian the Bishop, London 2002, p. 2

152 Dionysius of Alexandria was being hunted and Fabian of Rome was dying in prison, suggesting that bishops were targeted.

153 Wilhite, "Hermeneutic of Identity," n. 58, p. 77, agrees that this is the traditional theory, as offered by Cyprian in his letters and by Pontius in his bibliography

154 Clarke, Letters, Vol. 1, n. 2, p. 182, suggests there may have been a specific order to secure sacrificial compliance initially from bishops.

155 Burns, Cyprian the Bishop, p. 18.

156 This argument is evident in De Lapsis.

157 Ep. 14 (CCsL 3 B:79-84).

158 Ep. 34 (CCSL 3B: 65-67) "It is an astonishing revelation of Cyprian's thoroughgoing hierarchical attitude that he can, without any apparent embarrassment, accept flight for himself as being fully sanctioned and justified, but he can calmly require, at the same time, that his subordinate clergy should remain at their posts, continuing their ministries under the persecution." Clarke, Letters, Vol. 2, n. 18, p. 16o. Apparently, no one was clamouring for the unknown presbyters to be brought to the arena; because of their lower status they were able to visit the confessors in prison, unhindered. 
ity as bishop was to protect his flock from such violence, and this is the reason he gave for his withdrawal; to his clergy ${ }^{160}$ and to those at Rome. ${ }^{161}$

Right at the very first onset of the troubles, when the populace clamoured for me violently and repeatedly, I followed the directives and instructions of the Lord and withdrew for the time being. I was thinking not so much of my own safety as the general peace of our brethren; I was concerned that if I brazenly continued to show myself (in Carthage) I might aggravate even further the disturbance that had begun. ${ }^{162}$

Cyprian added an account of the episcopal duties he had undertaken and how his policy on the reconciliation of the lapsed was in harmony with Rome's. His defence here and elsewhere was his pastoral duty to maintain the peace of the church and continue to minister to, counsel and discipline the flock under his care. What did Cyprian mean by sicut Domini mandata instruunt? Clarke, against Fahey, suggests a scriptural injunction, specifically Mt 10:23. ${ }^{163}$ But Cyprian was more likely referring to his personal visionary directive, even allowing that Cyprian may not have felt the need to "explain" to clerics a citation of Mt 10:23. ${ }^{164}$ Clarke's reasoning is that Cyprian "is not prepared to invoke personally vouchsafed signs (as he does to his own clergy in Ep.16.4.1; cf. Ep.7.1); did he sense the vulnerability of such an argument?"165 Rome eventually re-

$160 \quad E p \cdot 7 \cdot 1$ (CCSL 3 B:38) and Ep. 16.3.2-16.4.1 (CCSL 3B:93-94).

161 The bishop-less clergy of Rome were now aware of Cyprian's "retirement." Ep. 8 (CCSL $\left.{ }_{3} \mathrm{~B}: 40-43\right)$. Clarke, Letters, Vol. 1, n.4, p. 208. notes their use of the terms relinquere, fugere, desesere, relicitio. They were concerned the church in Carthage was now also leaderless and reminded their Carthaginian brothers to be not hirelings, but good shepherds. Epistle 20 was Cyprian's response.

162 Nam, sicut Domini mandata instruunt, orio statim turbationis impetur primo, cum me clamore uiolento frequenter populus flagitasset, non tam meam salutem quam quietem fratrum publicam cogitans, interim secessi, ne per inverecundam praesentiam nostram, seditio quae coeperat, plus prouocaretur. Ep. 20.1.2 (CCSL 3 B: 106-7).

163 Clarke, Letters, Vol. 1, p. 307. Fahey, Cyprian and the Bible, 297, finds that "As such Cyprian never cites directly Mt 10:23a" and I agree that the connection in Ep 20.1.2 is tenuous. The link is much stronger in Laps. 10 (see below) which I consider to be Cyprian's only actual citation of this passage.

164 As would be inferred from Wilhite, "Hermeneutic of Identity," p. 82 "Those [letters] addressing clergy tend not to contain any scriptural citations, while those addressing clergy and laity, or exclusively laity, tend to be dense with quotations."

165 Clarke, Letters, Vol. 1, n.5, p. 308. That may be the case, but Cyprian's actual invocation of the Lord's directives is left very open to interpretation. It is unclear how he would have expected the Roman clergy to interpret it. 
versed their censorious position, exonerating Cyprian. ${ }^{166}$ However, Cyprian's opponents who had opposed his ordination, now undermined his leadership. ${ }^{167}$ The premature readmission of the lapsed by Cyprian's rebellious presbytery undermined the law of God and the authority of the bishop. These leaders were the butchers, not shepherds, of the flock. ${ }^{168}$ In contrast, Cyprian had obeyed God. ${ }^{169}$

Persecution waned and in De Lapsis ${ }^{170}$ we see a bishop no longer forced to justify his withdrawal, speaking authoritatively with the support of the wider episcopacy. He maintained that God had sent persecution as punishment for the church's worldliness; Christians would not relinquish possessions by fleeing and yet could not withstand the imminent persecution. ${ }^{171}$ Private confession, waiting for the Lord, is also a means to glory. Such a one withdraws in ordernottodenybut "would certainly confessifhetoo hadbeen apprehended."172 It was only in this context that Cyprian drew on Mt 10:23;"173 "therefore the Lord commanded us in the persecution to depart and flee; and both taught that this should be done, and himself did it."174

166 Ep. 30 (CCSL 3B:139-50). The Roman clergy concurred with Cyprian's stance on the lapsed, including the libellatici and made positive reference to other refugee bishops: Clarke, Letters, Vol. 2, p. 117, 131.

167 "By availing himself of the privilege of an honestiore to protect his people, Cyprian had disabled himself as a bishop: he could exert no face-to-face pressure to restore discipline or establish control. The church in Carthage was in danger of disintegration." Burns, Cyprian the Bishop, p. 23. Felicissimus' challenge brought into the open and helped to cohere the various groups dissatisfied with Cyprian, those critical of his appointment, his flight and his rigorous policies, Clarke, Letters, Vol. 2, p. 201. Clarke, Letters, Vol. 2, n.19, pp. 219-220 perceives a veiled threat from his clerical rivals who desired his absence at Easter.

168 Ep.15.1.2 (CCSL 3B:85-86). The subsequent reference to shepherds in 2.1 is arguably a response to specific criticism about Cyprian's own role. Cyprian further pairs rebellion against the Gospel with rebellion against the bishop in Ep.16.1.2 (CCSL 3B:90-91).

169 Ep. 16.3.2-16.4.1 (CCSL 3B:93-94).

170 Burns, Cyprian the Bishop, p. 4.

171 Cyprian, Laps. 5-7, 11-12 (CCSL 3:223-25, 226-27).

172 confiteretur utique si fuisset et ipse detentus. Cyprian, Laps. 3 (CCSL 3:222). An excuse which Tertullian, Fug. 5.1 (CCSL 2:1141) disallowed.

173 Cyprian, Laps. 10 (CCSL 3:226). Clarke, Letters, Vol. 1, p. 307-8, commenting on Ep. 20, notes the connection between allusions to Christ's withdrawals in Mt 4:12 and Jn 11:54, the use of Isa 52:11 and Rev 18:4, in conjunction with Mt 10:23 in Lap.s 10.

174 Et ideo Dominus in persecutione secedere et fugere mandauit, adque, ut id fierit, et docuit et fecet. Cyprian, Laps. 10 (CCsL 3:226). 
Following Decius' death in 251, the empire underwent a period of pessimism and uncertainty. The church became convinced that the end was near, the millennial tribulation was imminent and a dreadful persecution was about to break out. ${ }^{175}$ This, according to Cyprian, was not another chastening, but a final testing in anticipation of the return of Christ in judgement. Withdrawal was not appropriate now, and Cyprian stated his duty as bishop was to remain with the flock, as he wrote to the Thibarii. ${ }^{176}$ The Antichrist and day of affliction were imminent, as Christ predicted of the Last Days. Christians should rejoice and focus on confession and martyrdom. By death they would win their crowns. Nevertheless, Cyprian expected that Christians would be driven to flight and communities broken up. No one should fear the terrors of flight, with Christ as his companion. "The one who, preserving his temple of God is not alone, because he has God always with him wherever he may be."177 To die in such a situation makes him equally a martyr. Cyprian did not allude to Mt 10:23 here, ${ }^{178}$ but, given that both reprieve and persecution are providential, ${ }^{179}$ martyrdom is a glory visited on those God deems deserving and should not be presumed. ${ }^{180}$ Such was the case of those who prepared themselves for confession and martyrdom but died from the plague. There is no mention of flight in $D e$ Mortalitate, ${ }^{181}$ because Cyprian did not regard flight as a means of avoiding

175 Clarke, Letter,s Vol. 3, pp. 228-229. The church additionally experienced discord, heretics and schismatics.

${ }_{176} E p .5^{8}$ (CCSL 3B:319-335). Clarke, Letters, Vol. 3, p. 226, dates the letter c. May 253. For a detailed analysis of Ep. 58, see Nienke Vos, "A Universe of Meaning: Cyprian's use of Scripture in Letter 58," in Henk Bakker, Paul van Geest \& Hans van Loon, eds., Cyprian of Carthage: Studies in his Life, Language and Thought, Leuven, 2010, pp. 65-93.

177 Solus non est qui templum dei seruans ubicumque fuerit sine deo non est. Ep. 58.3.2, 4.2 (CCsL 3 B:323-24).

178 Vos, “Universe of Meaning," pp. 90-93, explains Cyprian's use of word repetition and military imagery throughout $E p .58$, but, surprisingly (and disappointingly) makes no comments on ch.4 or flight and his summary table is blank as to references or allusions for ch.4. "Flight" is out of place in Vos's scheme.

179 Cyprian, Mort. 19, (CCSL 3A:27) Laps. 1 (CCSL 3:221). I can only suggest that Cyprian thought it legitimate to flee to preserve oneself for the purpose of ultimately dying for Christ according to God's providence, but found the missionary context of Mt 10:23 out of step with his end times perspective.

180 Primo in loco on est in tua potestate, sed in Dei dignatione martyrium, nec potes te dicere perdidisse quod nescis an merearis accipere. Mort. 17 (CCSL 3A:23-24) Nevertheless, his letters could be as glorifying of bloody final conflict as anything Tertullian penned.

181 Fahey, Cyprian and the Bible, 21, assigns it to 252, as does Clarke, ACW 43, p. 45.J.H.D. Scourfield, "The De Mortalitate of Cyprian: Consolation and Context," Vigilanae Christiane 50 (1996), 12-41, p. 23 placed it as late as 253. 
suffering per se, even for those who had the means. It was appropriate to flee persecution, especially to avoid denial, and to preserve oneself for Christian work, but it was not appropriate to try to flee suffering as such. In fact, flight itself entails suffering and rather than being escape from trial, it may be part of it. ${ }^{182}$ Christians are not immune and in fact have the additional trial of doing battle with the devil in this world. ${ }^{183}$ People only fear to die if they have no faith, only the one who delights in the world wants to remain in it; a true foreigner wants to return home. ${ }^{184}$ Suffering leads to increased faith and that is really what God wants. ${ }^{185}$

Cyprian went further in Ad Fortunatum;186 "Christ exhorts his servants to martyrdom." ${ }^{187}$ Martyrdom is a second baptism which completes our salvation. ${ }^{188}$ Rather than pre-empting God's providence, martyrdom was now something to be embraced and desired and actually requested; flight is not mentioned. It was the job of bishops such as Cyprian and Fortunatus to prepare their people for it. ${ }^{189}$ We must persevere to the end, we must not conform to the world but be transformed; we glory in tribulations. ${ }^{190} \mathrm{God}$ helps his people in their persecutions, but not by allowing them escape. The help is God's presence with them in persecution; the Holy Spirit will give them what to speak (Mt 10:18-20). ${ }^{191}$ When persecution resumed under Valerian, ${ }^{192}$ Cyprian

182 Confiscation of property had been common in the Decian persecution, and Christian refugees would have had to leave their possessions and tools of trade. Clarke, Letters, Vol.2, n. 6, p. 205 .

183 Cyprian, Mort. 4, 9-10 (CCSL 3A:18-19, 21-22).

184 Cyprian, Mort. 5-8, 21-26 (CCSL 3A:19-21, 28-32).

185 Cyprian, Mort. 13-15, 17-18 (CCSL 3A: 23-27). This is reminiscent of Clement's idea of the whole life well lived for God.

186 The date of Ad Fortunatum, also known as Exhortation to Martyrdom, is unclear. Clarke, Letters, Vol. 1, p. 45 tentatively places it in 250, under Decius. Fahey, Cyprian and The Bible, p. 21, prefers 253 to the possibility of 257 , largely on the basis of 253 being a period of his greater literary activity. I suggest either 253 or 257 would fit with the anticipation of persecution, but I cautiously favour 257 because Cyprian seemed to be exhorting himself as much as his fellow bishop Fortunatus to their duty of preparing Christians for martyrdom (4), and stressed the inevitability and continuity of Christian persecution (11). See Clarke, Letters, Vol. 3, p. 228-9, describing Cyprian's view of the final decline of the world.

187 seruos suas ad martyrium Christus hortatur. Cyprian, Fort. Praef.4 (CCSL 3:184).

188 Cyprian, Fort. Praef.4 (CCSL 3:184-5).

189 Cyprian, Fort. Praef. 4 (CCSL 3:184-5).

190 Cyprian, Fort. 8-10(CCSL 3:195-102).

191 Cyprian, Fort. 10 (CCSL 3:198-201).

192 See Clarke, Letters, Vol. 4, pp. 8-14 for an excellent summary of the evidence for this persecution. 
put thisinto practice. He madehis public confession and was exiled to Curubis, ${ }^{193}$ an appropriate punishment for a persona insignia. ${ }^{194}$ When Valerian focused on senior Christian clergy, ${ }^{195}$ Cyprian knew his time had come to be martyred and returned to Carthage. ${ }^{196}$ He underwent a brief withdrawal of an entirely different kind; to avoid being tried and executed at Utica. ${ }^{197}$

It befits a bishop to confess his faith in that city where he has been placed in charge over the Lord's flock, it is proper that the appointed leader in the Church should bring glory upon all his people by making his confession in their midst. For whatever a confessor-bishop speaks at the very moment he confesses his faith, he speaks under the inspiration of God and as the mouthpiece of all. ${ }^{198}$

For the honour of the Carthaginian church it should be at Carthage, not Utica, that their bishop confessed, suffered and went forth to the Lord, and so he did. 199 Montgomery, following Bobertz, argues that Cyprian's decisions were informed by a patronage relationship with his flock. ${ }^{200}$ He initially withdrew himself to protect his clients from the danger provoked by his presence. The reward for patronage was honour from the clients, and this he sought to receive in being martyred in their presence rather than in exile. Dunn, against Bobertz, argues that Cyprian initially rejected the model of patronage along with his wealthy

\footnotetext{
193 Ep. 76.1.1 (CCSL 3C:605-6).

194 Clarke, Letters, Vol. 4, pp. 277-8, 281.

195 Clarke, Letters, Vol. 4, n.20, p. 285. From Curubis he exchanged letters of encouragement and consolation to the Numidian bishop confessors in the mines; Epp. 76-79.

196 Ep. 80 (CCSL 3 C:626-28) contains a warning from Cyprian to bishop Successus of Valerian's rescript ordering the death of bishops, presbyters and deacons. He was confined to Carthage with his faithful clergy, ready to endure suffering and receive the martyr's crown.

197 Ep. 81 (CCSL 3C:629-30).

198 eo quod congruat episcopum in ea ciuitate in qua Ecclesiae Dominicae praeest, illic Dominum confiteri et plebem uniuersam paepositipraesentis confessione clarificari. Quodcumque enim sub illo confessionis momento confessor episcopus loquitur, aspirante Deo, ore omnium loquitur. Ep. 81.1- 1.2 (CCsL 3 C:629).

199 Clarke, commenting on Ep 58, writes, "Cyprian long contemplated the scene in which he, as bishop, inspired with his martyr's dying words as the Gospel promised him, should go forth to his death witnessed by these plebs whom he has led and bringing glory upon them... Cyprian's tone in this letter suggests he is now preparing himself for such a heroic role." Clarke, Letters, Vol. 3, p. 228.

200 Hugh Montgomery, "The Bishop who fled: Responsibility and honour in Saint Cyprian," Studia Patristica, 21 (1989), pp. 264-270. Others have built on the seminal work of Charles A. Bobertz, Cyprian of Carthage as patron : a social historical study of the role of bishop in ancient Christian community of North Africa, PhD thesis, 1988, Michigan, $2004<$ https:// trove.nla.gov.au/version/8672834>.
} 
and privileged lifestyle, ${ }^{201}$ but later appealed to it to motivate wealthy Christians to care for the poor, especially those who lost everything in the persecution. ${ }^{202}$

Cyprian fled Carthage in 250 in order to care for his flock; he subsequently had episcopal responsibility to fix the mess that had occurred in his absence. Now, as bishop he would be martyred with the support (and patronage) of his people. Flight for Cyprian the bishop was according to providence in given situation and his first loyalty was to his role as bishop. It provided the context for following divine commands, be they channelled through scripture or through direct inspiration. In this broad picture, Mt 10:23 played the most minor of roles.

\section{Conclusion}

I propose that, rather than trying to place "flight" somewhere on a continuum from apostasy to martyrdom, it has a spectrum of its own. Flight may itself be a form of suffering for Christ, as Cyprian asserted. It may be part of a more holistic view of the Christian life, as for Clement and Origen, and avoid complicity in the persecutors' sins. Nevertheless, as Tertullian stressed, flight might also result from fear. All four valued martyrdom. Tertullian made no public confession, and used Mt 10:23 according to his varying rhetorical agenda. Origen and Cyprian, who both initially withdrew and then did confess, found a valid place for flight. Origen's theology of a providential God led him to eschew violence and accept the prudence of withdrawal to preserve one for continuing God's work. Clement's concept of the gnostic Christian and martyrdom as a whole life well lived for God steered him down a middle course of accepting death without actively courting it. A contemporary application of Mt 10:23 sat comfortably with the two Alexandrians. Cyprian's theology of the role of bishop, within the changing context of his experiences, determined his responses to persecution. He derived his divine directives from direct inspiration as the conduit of God's Spirit rather than detailed exegesis of Mt 10:23. Nevertheless, the common thread that tied together the four writers' perspectives on how one should respond to persecution was the unwavering commitment to confessing, not denying, the Christ who had died for them.

\footnotetext{
201 Such a rejection of the trappings of his status fits well with Cyprian's reflections in $A d$ Donatum, especially 3-4 (CCSL 3A:4-5), thought to be written shortly after his conversion.

202 Geoffrey D. Dunn, "The White Crown of Works: Cyprian's Early Pastoral Ministry of Almsgiving in Carthage," Church History 73:4, (2004), pp 715-740, 717-18.
} 